\title{
The Suitability of Reading Materials in English Textbook Used for Junior High School to the 2013 Curriculum
}

\author{
${ }^{1}$ Sri Okta Bella, ${ }^{2}$ Albert \\ ${ }^{1}$ State Islamic Institut of Bukittinggi (LAIN) Bukittinggi, e-mail: srioktabela131098@gmail.com \\ ${ }^{2}$ Haji Agus Salim College of Foreign Languages, Bukittinggi, e-mail : natsir.albert12@gmail.com
}

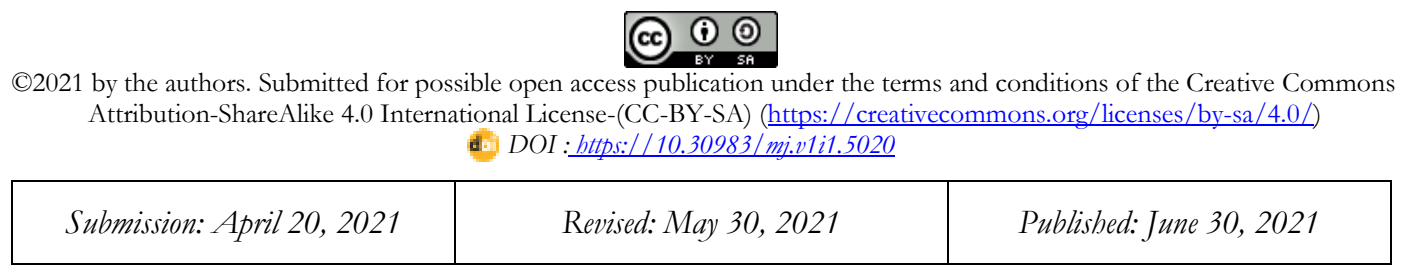

\begin{abstract}
Abstrak
Buku teks merupakan salah satu sumber bahan ajar yang digunakan guru dalam mengajarkan bahan bacaan. Di Indonesia, penggunaan buku teks sebagai bahan ajar untuk kegiatan membaca secara intensif harus sesuai dengan kurikulum 2013 sebagai kurikulum yang berlaku saat ini. Penelitian ini bertujuan untuk mengetahui kesesuaian bahan ajar membaca di dalam buku teks dengan kurikulum 2013 untuk aspek relevansi, konsistensi, dan kecukupan. Teknik kuantitatif digunakan dalam penelitian ini. Data penelitian dikumpulkan dari dua buku teks bahasa Inggris, buku bahasa Inggris kelas 7 untuk Sekolah Menengah Pertama yang diterbikan oleh Kementerian Pendidikan dan Kebudayaan, dan Yudhistira. Sampel diambil dengan menggunakan purposive sampling yang dipilih sesuai dengan pilihan peneliti dan tujuan penelitian. Adapun instrumen penelitian yang digunakan yaitu lembar penilaian untuk buku teks. Penelitian ini menemukan bahwa dari aspek relevansi dalam buku When English Rings Bell yang diterbitkan oleh Kementerian Pendidikan dan Kebudayaan dan buku teks yang diterbitkan Yudhistira dikategorikan "Cukup" dengan persentase masing-masing 76\%. Selanjutnya dari aspek konsistensi, buku When English Rings Bell dikategorikan "Buruk" dengan persentase 16\%, sedangkan pada buku 2 dikategorikan "Baik" dengan persentase $82 \%$. Terakhir, dari aspek kecukupan, baik buku When English Rings Bell yang diterbitkan Kementerian Pendidikan dan Kebudayaan, maupun Yudhistira menempati kategori yang sama dikategorikan "cukup" dengan persentase masing-masing $61 \%$. Disimpulkan, berbeda dengan aspek konsistensi, kedua buku teks bahasa Inggris yang diteliti ini dikategorikan cukup untuk aspek relevansi dan kecukupan. Artinya, kedua buku teks bahasa Inggris memiliki kelebihan dan kekurangannya dalam konteks kesesuaianya dengan kurikulum 2013.
\end{abstract}

Kata kunci: Bahan Ajar Membaca, Buku Teks Bahasa Inggris, Kurikulum 2013

\begin{abstract}
Textbook is one of the sources of teaching materials used by teachers in teaching reading skills. In Indonesia, the use of textbooks as teaching materials for intensive reading activities must be in accordance with the 2013 curriculum as the current curriculum. This study aims to determine the suitability of reading teaching materials in textbooks with the 2013 curriculum for aspects of relevance, consistency, and adequacy. Quantitative techniques were used in this study. The research data were collected from two English textbooks, the 7th grade English book for Junior High School published by the Ministry of Education and Culture, and Yudhistira. Samples were taken using purposive sampling which were selected according to the researcher's choice and research objectives. The research instrument used was an assessment sheet for textbooks. This study found that from the aspect of relevance, the book When English Rings Bell published by the Ministry of Education and Culture and the textbook published by Yudhistira were categorized as "Enough" with a percentage of $76 \%$ each. In the aspect of consistency, the book When English Rings Bell was categorized as "Bad" with a percentage of $16 \%$, while in book published by Yudhistira was categorized as "good" with a percentage of $82 \%$. Lastly, in the aspect of adequacy, both the text books published by the Ministry of Education and Culture, and Yudhistira occupied the same category, it was "enough" with a percentage of $61 \%$ each. In conclusion, in contrast to the aspect of consistency, the two English textbooks studied were categorized as adequate for the aspects of relevance and adequacy. That is, both English
\end{abstract}


textbooks have their strengths and weaknessesin the context of their suitability with the 2013 curriculum.

Keywords: Reading Material ,English Texbook,Curriculum 2013

\section{Introduction}

Textbooks play an important role in effective teaching and learning (Abdelraheem, A. Y., \& Al-Rabani, 2005). In term of English language teaching, the textbooks are frequently used by most English teachers as a key source of ideas and instructional activities, as well as a guide for what they do. Teachers, learners and other stakeholders depend to a great extent on books for knowledge development, skills and attitudes (Richards, J.C., \& Rodger, 2001). In addition, textbooks enrich the treasures of insight for teachers both in planning lessons, teaching methods to be adopted, as well as teaching aids used (Bitekeye A, 2010).

As the primary teaching resources in English as a foreign language classes, English textbooks also play a critical role in facilitating language acquisition in classrooms. In Indonesia, the selection of textbooks as teaching materials for intensive reading activities must be in accordance with the 2013 curriculum as the current curriculum. According to the Minister of Education and Culture's Regulation No. 71, article 1 of 2013, there are two books used as reference books in learning in the 2013 curriculum: the student book and the teacher's book. Student books are the most important learning materials for acquiring basic and core competencies (The Ministry of Education and Culture of Republic of Indonesia, 2013). Meanwhile, the teacher's manual contains guidelines for each topic and/or learning theme, including learning strategies, learning methods, learning approaches, and assessments. These must be meet the principles as lined in the 2013 curriculum mostly encompassing the aspect of relevancy, consistency, and adequacy.

Mursini proposesthe principles for selecting textbook materials which include relevance, consistency, and adequacy. Relevance is defined as a connection in which the materials must be relevant to core and basic competencies. This allows the teacher to avoid selecting resources that are not relevant to standard and basic competency. As a result, the teacher must be be able to determine whether the materials are facts, concepts, principles, procedures, attitudes, and psycomotoric aspects. The quality and the relevant textbook are fundamental for a child to achieve and excel in performance (Graves, 2009; Haulle, 2001; UNESCO, 2011; Chisholm, 2013).

Consistency means the suitability of the materials in the textbook to the core and basic competency in the 2013 curriculum. Meanwhile, adequacy means that the material in the textbook must be sufficient to help students master the core and competency-based basic material. The material should provide sufficient information to help students achieving the core competencies and basic competencies without wasting time and energy to learn it.

In reading material, textbook plays an important role since it provides the learning material which can improve students' reading skills through intensive reading activities. Consequently, reading teaching materials in texbooks must be in accordance with 2013 curriculum, in terms of aspects of relevance, consistency, and adequacy. Thus, it is important to analyze the suitability between the learning materials of the reading materials to the 2013 curriculum in terms of the aspects of relevance, consistency, and adequacy. The 2017 English textbook published by the Ministry of Education and Culture is entitled When English Rings A Bell: Course for Junior High School Written by Siti Wachidah, Asep Gunawan, Diyantari, Yuli Rulani Khatimah. It has eight chapters and consists of 177 pages. Furthermore, an English textbook entitled Interactive English 1 Junior High School Year VII was written by Kenneth W.Ament and Rina Dwi Indriastuty. It has eight units and consists of 156 pages, used as a learning resource by teachers and students. Therefore, researchers will compare which books have more relevance, consistency, and adequacy focus on reading material with the 2013 curriculum. 


\section{Research Method}

The kind of this research is descriptive quantitative research. The samples are When English Rings a Bell which is published by the Ministry of Education and Culture of Republic Indonesia, and Interactive English 1 which is published by the publishing of Yudhistira. These were selected using purposive sampling technique and used for 7th grade students of Junior High School. The researcher analyzed the data from the textbook using score category assesment. The step of data analysis encompassing: 1.comparing the materials provided within the textbook with the theme suggested by the Curriculum 2013; 2. evaluating the materials presented in the textbooks; 3.interpreting the data gained from process of evaluation of the English textbook, and 4. summing up the compatibility of the textbook content in quantitative output to show the result in percentage.

\section{Findings and Discussion}

The table below shows the suitability of reading learning material in When English Rings a Bell which is published by the Ministry of Education and Culture of Republic Indonesia, and Interactive English 1 which is published by the publishing of Yudhistira.

Table 1

The Percentages of Analysis of Suitability of Reading Material to the

\section{Curriculum}

\begin{tabular}{|lccc|}
\hline Num. & Aspect & When English Rings a Bell & Interactive English 1 \\
\hline 1. & Relevancy & $76 \%$ & $76 \%$ \\
\hline 2. & Consistency & $16 \%$ & $81 \%$ \\
\hline 3. & Adequency & $61 \%$ & $64 \%$ \\
\hline & Total of Score & $153 \%$ & $221 \%$ \\
\hline & Percentages & $51 \%$ & $74 \%$ \\
\hline & Criteria & Sufficient & Fair \\
\hline
\end{tabular}

The table above indicates that generally the textbook of Interactive English 1 achieves the higher value, that is $74 \%$, than the book of When English Rings a Bell which only gets $51 \%$ in term of the suitability of reading material to the 2013 curriculum. The aspect of relevancy encompassing gentre of text, social-function, topic, and 4). reading skill. The consistency of text book refers to the providing of the activity of pre-reading, reading strategy, variation of reading task, and test for reading comprehension. Then, the adequacy aspect belongs to the providing of descriptive texts, reading activities, and test of reading ability. The achievement for each aspect is provided as follows:

\section{(1) Relavancy}

In term of relevancy, the percentage value of the textbooks is $76 \%$ which means respectively. In detail, the aspect of genre text in the textbook of When English Rings a Bell is $86 \%$, and Interactive English 1 is $71 \%$. The aspect of social functions in all textbooks is $100 \%$. In percentage value for the aspect of relevancy to the 2013 curriculum is $50 \%$ for the former textbook and $54 \%$ for the later. In term of reading skills, the former book achieves $86 \%$, and the later is $86 \%$.

\section{(2) Consistency}

The percentage value of pre-reading activity is $79 \%$ for textbook of When English Rings a Bell and $100 \%$ for Interactive English 1 which means that all the reading materials in the textbook is began by the pre-reading activity. In terms of providing of reading 
srategies, the percentage value of former book is $29 \%$ and the later is $65 \%$. In term of task variation, the percentage value of former textbook is only $43 \%$, and the later is $97 \%$. For the task for reading comprehension, the percentage value of former book is $43 \%$, and $65 \%$ for the later.

\section{(3) Adequency}

This aspect encompassing the providing of descriptive text, the reading activities, and test of reading ability. The percentage values of When English Rings a Bell and Interactive English 1 are $54 \%$. These books also have the same percentage value for the providing of reading activities, that is $100 \%$. It means that each chapter in the texbooks provides the reading activities. Nevertheless, the percentage value of the former textbook for the providing of reading ability test is just $36 \%$, and $50 \%$ for the later.

Generally, the book of Interactive English 1 is superior to the book of When English Rings $A$ Bell in terms of the suitability of reading material to the 2013 curriculum. Nevertheless, the two books have met the aspects of relevance to the 2013 curriculum. This means that the availability of various text genres and social functions, topics, and reading skills is relevant to the 2013 Curriculum. The book of When English Rings a Bell achieves low percentage value on the aspect of consistency. This aspect concerns on the availability of pre-reading activity for each reading materials, reading strategies explanation, variatious reading task, and comprehensive reading test. This fact is much different when compared to the book of Interactive English 1 in which it has averagely met the criteria as the appropriate textbook for reading materials under the principles of the 2013 curriculum.

\section{Conclusion}

It is concluded that the book of When English Rings a Bell which is published by the Ministry of Education and Culture still has some weaknesses mostly in the aspect of consistency and adequacy which are related to the 2013 curriculum. On the contrary, the book of Interactive English 1 which is published by Yudhistira Publishing meets more criteria of suitability to the 2013 curriculum in term of reading material. Consequently, this book is more recommended as the main reference especially for teaching reading skill.

\section{References}

Abdelraheem, A. Y., \& Al-Rabani, A. H. (2005). No Title. Malaysian Online Journal of Instruction Technology., Vol. 2(1), 1-4.

Bitekeye A. (2010). Govt Throws the Final Shocker. The ,Citizen. http://www.thecitizen.co.tz/magazine/success/.

Chisholm, L. (2013). NoThe Textbook Saga and Corruption in Education Title. Southern African Review of Education, Vol. 19(1), 7-22.

Graves. (2009). Designing Language Courses: A Guide for Teacher. Thomson Heinle.

Haulle, Evaristo and Kabelege, E. (2021). Relevance and Quality of Textbooks Used in Primary Education in Tanzania: A Case of Social Studies Textbooks. Journal Contemporary Education Dialogue, Vol.18 (1), 12-28. 
Richards, J.C., \& Rodger, T. . (2001). Approaches and Methods in Language Teaching. Cambridge University Press.

The Ministry of Education and Culture of Republic of Indonesia. (2013). Students' Book: When English Rings a Bell. Kemendikbud: Jakarta.

UNESCO. (2011). The Hidden crisis: Armed Conflict and Education. In Retrieved from bttp:/ / www. efareport.unesco.org. 